\title{
C-trisomy in a case of neonatal leukaemia
}

\author{
M F WHITFIELD, D G D BARR, AND MAUREEN L O'RIORDAN
}

\begin{abstract}
Department of Child Life and Health, University of Edinburgh, and MRC Clinical and Population Cytogenetics Unit, Western General Hospital, Edinburgh
\end{abstract}

SUMMARY A case of neonatal leukaemia of acute myeloid cell type was diagnosed at age 8 weeks and the patient died shortly afterwards with evidence of disseminated intravascular coagulation. An aneuploid malignant cell line $47, X Y+C$ was found, in addition to the infant's normal constitutional karyotype. Eight other cases of congenital or neonatal leukaemia with aneuploid malignant cell lines are reviewed. C-trisomy is a commonly acquired chromosomal abnormality in a wide range of malignant and premalignant haematological disorders, and its possible significance in relation to leukaemogenesis in this case is discussed.

Only eight cases of neonatal leukaemia with aneuploid malignant cell lines occurring in chromosomally normal infants have been reported to date. ${ }^{1-8}$ The present child, a phenotypically normal male, had an aneuploid malignant cell line showing C-group trisomy. The clinical course, and relevance of this particular karyotype are described.

\section{Case report}

A boy born at term, weighing $3.44 \mathrm{~kg}$, was the second child of a 30-year-old woman. There was no history of maternal illness or drug ingestion during pregnancy nor had there been a previous abortion. The mother had had two abdominal $x$-rays in midchildhood but no $x$-ray exposure during pregnancy.

The infant developed moderate physiological jaundice reaching a maximum indirect bilirubin level of $210 \mu \mathrm{mol} / 1(12 \cdot 3 \mathrm{mg} / 100 \mathrm{ml})$. Both the mother and baby were group B Rh-positive and the baby's direct Coombs's test was negative. At age 7 weeks he developed cough and wheeze, and thereafter became progressively more irritable and listless with screaming attacks. Extreme pallor, deterioration in feeding, and the presence of melaena led to his admission to hospital at 8 weeks where he was noted to be well nourished but pale and irritable. There was head retraction, the fontanelle was tense and bulging, and there was congestion of the fundal veins, but no frank papilloedema. The liver and spleen were both hard, smooth, and 3-4 cm below the costal margin. There was a scattered discrete, generalised lymphadenopathy and a few cutaneous ecchymoses.

Haemoglobin $(\mathrm{Hb})$ was $3.1 \mathrm{~g} / \mathrm{dl}$, platelets $<$
$10.0 \times 10^{9} / 1$, white cell count $1070 \times 10^{9} / 1$, blasts $73 \%$, promyelocytes $1 \%$, lymphocytes $24 \%$, monocytes $2 \%$, There was total replacement of normal haemopoietic tissue in the marrow by primitive cells. These cells were of two types. The more numerous had dense-staining nuclear chromatin and relatively little cytoplasm, and were Sudan black negative but periodic acid-Schiff positive. The other type were larger and contained at least 3 blue-staining nucleoli. These cells had some Sudan black positive granules, and a few had periodic acid-Schiff positive blocks. These cells resembled reticulum cells.

Skull $x$-ray was normal, chest $x$-ray showed slight cardiomegaly, and the bone texture was normal on all $x$-rays taken. Cerebrospinal fluid had no increase in cells but protein was slightly increased at $0.6 \mathrm{~g} / 1$ $(60 \mathrm{mg} / 100 \mathrm{ml})$.

Full bacteriological infection screen, viral serology for cytomegalovirus, and rubella were negative, and Venereal Disease Research Laboratory test of mother's blood at the antenatal clinic was negative.

Plasma urea and electrolytes were normal apart from a low bicarbonate level of $14.5 \mathrm{mmol} / \mathrm{l}$, but the uric acid level was grossly raised at $0.67 \mathrm{mmol} / 1$ $(11 \cdot 2 \mathrm{mg} / 100 \mathrm{ml})$.

After packed cells and platelet transfusion, treatment with allopurinol $50 \mathrm{mg}$ daily and prednisolone $15 \mathrm{mg}$ daily was started while full morphological and cytochemical evaluation of the marrow was carried out. After transfusion $\mathrm{Hb}$ rose to $11.6 \mathrm{~g} / \mathrm{dl}$ and platelets to $37.0 \times 10^{9} / 1$. This was accompanied by a considerable improvement in the patient's general condition and there was no further overt bleeding. On the basis of the rather ambiguous histological appearance and cytochemical staining 
properties of the marrow, and the lack of response in white cell count after 5 days of treatment with prednisolone, corticosteroids were stopped and treatment started with the quadruple cytotoxic regimen recommended by the British Medical Research Council for acute myeloid leukaemia in childhood. The induction therapy was thioguanine $100 \mathrm{mg} / \mathrm{m}^{2}$ orally on days 1 to 5 , cystosine arabinoside $100 \mathrm{mg} / \mathrm{m}^{2}$ intravenously on day 1 and subcutaneously on days 2 to 5 , daunorubicin $40 \mathrm{mg} / \mathrm{m}^{2}$ intravenously on day 1 , and vincristine $1.5 \mathrm{mg} / \mathrm{m}^{2}$ intravenously on day 1 . He received 2 days of full treatment and by the second day there was a reduction in the white cell count, with some necrotic cells evident in peripheral blood smears. Platelets were maintained at $44.0 \times 10^{9} / 1$, but despite this the baby began to bleed profusely from new heel stab sites, and spontaneous oozing-which proved difficult to control-occurred from sites of venepunctures carried out several days previously.

A coagulation screen showed evidence of disseminated intravascular coagulation and the baby died 12 hours later from a massive gastrointestinal haemorrhage. Necropsy permission was refused.

Cytogenetic studies. Examination of the $\mathrm{X}$ and $\mathrm{Y}$ chromatin of the buccal mucosal cells showed a result consistent with a normal male XY sex chromosome complement. Unfortunately peripheral blood was the only tissue available for cytogenetic analysis. Studies were carried out on cultured lymphocytes stimulated with phytohaemagglutinin (PHA) and examination of orcein and G-banded preparations showed a 46,XY karyotype. 10 cells were examined from a 24-hour blood culture, grown without the addition of PHA, and 7 of these cells contained 47 chromosomes. The additional chromosome belonged to the $\mathrm{C}(6-12+\mathrm{X})$ group, but it was not possible to identify it more precisely using chromosome banding techniques as the chromosome morphology was poor. The remaining nonmodal cells showed random chromosome loss. These results indicate the presence of an acquired abnormal chromosome complement in the malignant cell line, not reflected in the constitutional karyotype. Parental karyotypes were both normal.

\section{Discussion}

The clinical, blood and marrow findings, the exclusion of identifiable causes of a leukaemoid reaction, and the presence of an aneuploid malignant cell line confirm this as a case of acute leukaemia. The cellular morphology, cytochemical staining characteristics, and lack of response in peripheral blood leucocyte count after 5 days of high dosage prednisolone are compatible with the malignant cell line being myeloblastic-monoblastic (M4) although

Table Neonatal leukaemia: cases with aneuploid malignant cell line

\begin{tabular}{|c|c|c|c|c|c|}
\hline Author & $\begin{array}{l}\text { Age at } \\
\text { presentation }\end{array}$ & Cell type & Tissue & Karyotype & Treatment \\
\hline Hungerford 3 & 3 months & Lymphoblastic & $\begin{array}{l}\text { Blood + PHA } \\
\text { Marrow }\end{array}$ & $\begin{array}{l}46, X Y,-C+E \text {, in } 1 \text { cell out } \\
\text { of } 7 \text { counted } \\
46, X Y,-C,+E \text { in } 1 \text { cell out } \\
\text { of } 8 \text { counted }\end{array}$ & None \\
\hline Zussman et al. ${ }^{8}$ & Birth & $\begin{array}{l}\text { Promyelocytic/ } \\
\text { myeloblastic }\end{array}$ & $\begin{array}{l}\text { Blood + PHA } \\
\text { Fibroblasts } \\
\text { Marrow }\end{array}$ & $\begin{array}{l}46, X Y \\
46, X Y \\
50 \% 46, X Y, 3 p-\end{array}$ & None \\
\hline Wagner et al. ${ }^{7}$ & 2 days & Lymphatic & Blood + PHA & $\begin{array}{l}\text { Mixed. Hyperdiploid. } \\
\text { Extra GEFC }\end{array}$ & $\begin{array}{l}\text { Prednisolone +6-MP for } \\
2 \text { months }\end{array}$ \\
\hline Bauke et al.1 & Birth & Myelomonocytic & $\begin{array}{l}\text { Blood + PHA } \\
\text { Marrow } \\
\text { Marrow in } \\
\text { remission }\end{array}$ & $\begin{array}{l}46, X X \\
46, X X,+D,-16 \\
46, X X\end{array}$ & $\begin{array}{l}\text { Before treatment } \\
\text { After } 6 \text { months of } \\
\text { prednisolone }+6-\mathrm{MP}\end{array}$ \\
\hline Ponzone et al.4 & 1 week & Myeloblastic & $\begin{array}{l}\text { Blood + PHA } \\
\text { Marrow }\end{array}$ & $\begin{array}{l}46, X X \\
90 \% \text { of cells } \\
46, X X, t(B q+, D q-)\end{array}$ & Before treatment \\
\hline $\begin{array}{l}\text { Van den Berghe } \\
\text { et al. } 6\end{array}$ & Birth & Myeloid & $\begin{array}{l}\text { Blood without } \\
\text { PHA }\end{array}$ & $46, X \times, t(B q+C q-)$ & None \\
\hline Sharp et al.5 & 6 weeks & Lymphatic & $\begin{array}{l}\text { Blood + PHA } \\
\text { Blood without } \\
\text { PHA } \\
\text { Marrow } \\
\text { Marrow in } \\
\text { remission }\end{array}$ & $\begin{array}{l}46, X Y \\
\text { No growth } \\
45, X Y,-2 G,-E+C,+ \text { mar } \\
46, X Y\end{array}$ & $\begin{array}{l}\text { Before treatment } \\
3 \text { weeks of } 6-M P \text { and } \\
\text { methotrexate }\end{array}$ \\
\hline Bjöness et al.2 & Birth & Myeloid & $\begin{array}{l}\text { Blood + PHA } \\
\text { Fibroblasts }\end{array}$ & $\begin{array}{l}47, X Y,+G \\
47, X Y,+G\end{array}$ & None \\
\hline $\begin{array}{l}\text { Whitfield } \text { et } \text { ul. } \\
\text { (present case) }\end{array}$ & 7 weeks & Myeloid & $\begin{array}{l}\text { Blood + PHA } \\
\text { Blood without } \\
\text { PHA }\end{array}$ & $\begin{array}{l}46, X Y \\
46, X Y,+C\end{array}$ & Before treatment \\
\hline
\end{tabular}

PHA = phytohaemagglutinin, 6-MP = 6-mercaptopurine, GEFC $=$ extra chromosomes in these groups. 
the appearances are not typical. ${ }^{9}$ It is particularly difficult to identify the precise cell type in neonatal leukaemia. ${ }^{10}$

Although the age of presentation lies marginally outside that accepted for a diagnosis of neonatal leukaemia, the clinical and haematological features strongly support such a diagnosis; the case is similar to the third group defined by Pierce ${ }^{11}$ in whom myeloid leukaemia presents at 3 to 6 weeks.

In nonmongoloid cases of congenital and neonatal leukaemia, the chromosome findings are generally normal although simultaneous determination of the malignant cell line, constitutional cell line, and that of the parents is lacking from most reported cases.

Eight patients with congenital or neonatal leukaemia have been recorded in whom chromosome studies have shown an aneuploid malignant cell line in an otherwise normal child, and these and our own case are summarised in the Table. The patient of Bjöness et al. ${ }^{2}$ although phenotypically normal, seems likely to have had Down's syndrome.

The significance of $\mathrm{C}(6-12+\mathrm{X})$ trisomy in the malignant cell line of our case has to be viewed in the wider context of chromosomal abnormalities found in other leukaemias. In the acute leukaemias a lack of cytogenetic uniformity has been found in extensive studies, but in the acute transformation stage of chronic myeloid leukaemia, the acute leukaemias, and in a variety of other myeloproliferative disorders, gain or loss of $\mathrm{C}$-group $(6-12+\mathrm{X})$ chromosomes has been described. Rowley's series ${ }^{12}$ appeared to show an increased incidence of disorders of chromosome 8 among such patients for which there was no satisfactory explanation. The First International Workshop on Chromosomes in Leukaemia ${ }^{13}$ has since confirmed this finding, trisomy-8 and monosomy-7 being the most common karyotype aberrations identified in a group of 139 adult patients with acute nonlymphocytic leukaemia. Rowley ${ }^{12}$ suggested that the genetic constitution of chromosome 8 might be responsible for its apparent predisposition to nondisjunction in these malignant or premalignant cells, or possibly it is 'the site of insertion or activation of a specific oncogenic virus or other agent'. The chromosome abnormality found in the malignant cell line might be specific for the oncogenic agent causing the tumour, rather than the clinical disease entity, the clinical manifestations of this chromosome change depending on a separate group of triggering influences. It is unfortunate that the specific identity of the extra C-group chromosome in our case could not positively be identified due to 'fuzziness' of the preparations.

The occurrence of disseminated intravascular coagulation has not previously been described in neonatal leukaemia, but is a well-known feature of acute promyelocytic leukaemia (M3) in adults, particularly in patients whose cells contain Auer rods. ${ }^{14}$ Our patient did not have Auer rods, nor did he have the karyotype abnormality peculiar to, but not invariably found in, $M 3, t(15 q+, 17 q-)$.

Although the other patients with aneuploidy in congenital or neonatal leukaemia had no uniform karyotype abnormality, the occurrence of C-trisomy in our patient with neonatal acute myeloid leukaemia links the disorder with a spectrum of myeloid-related malignant and premalignant haematological disorders in older patients sharing a similar karyotype abnormality, and suggests there may be a common aetiological factor in leukaemogenesis, irrespective of age. Chromosome analysis of unstimulated blood or marrow samples in addition to PHA-stimulated cultures should be carried out in all cases of congenital and neonatal leukaemia and other bizarre neonatal blood disorders, to determine the frequency of occurrence and importance of C-group abnormalities in haemopoietic tissues in the newborn period.

We thank Dr Elizabeth Innes, Department of Haematology, Royal Hospital for Sick Children, Edinburgh for help in the management of this case and preparation of this paper.

\section{References}

1 Bauke J, Cremer H J, Heimpel H. Kongenitale myelomonocytäre Leukämie mit aneuploider Stammlinie. $Z$ Kinderheilk 1970; 108: 288-96.

2 Bjöness H, Bühler M, Fricker H, Gugler E. Kongenitale Leukämie mit Chromosomenveränderungen (Trisomie G) bei einem nicht-mongoloiden Kinde. Helv Paediatr Acta 1974; 29 : 457-70.

3 Hungerford D A. Chromosome studies in human leukemia. I. Acute leukemia in children. J Natl Cancer Inst $1961 ; 27$ : 983-1011.

4 Ponzone A, De Sanctis C, Fabris C, Ciriotti G, Franceschini $P$. Blast cell proliferation in perinatal leukaemia with chromosomal translocation $(\mathrm{Bq}+, \mathrm{Dq}-)$. Helv Paediatr Acta 1972; 27 : 3-13.

5 Sharp J C, Potter A M, Guyer R J. Letter: Chromosome changes in congenital lymphoblastic leukaemia. Lancet 1973; ii: 1448.

6 Van den Berghe H, Fryns J P, Verresen H. Congenital leukaemia with $46, \mathrm{XX}, \mathrm{t}(\mathrm{Bq}+, \mathrm{Cq}-)$ cells. $J$ Med Genet 1972; 9: 468-70.

7 Wagner H P, Tönz O, von Greyerz-Gloor R D. Congenital lymphoid leukaemia. Case report with chromosomal studies. Helv Paediatr Acta 1968; 23 : 591-610.

8 Zussman WV, Khan A, Shayesteh P. Congenital leukemia. Report of a case with chromosomal abnormalities. Cancer 1967; 20; 1227-33.

- Bennett J M, Catovsky D, Daniel M T, et al. Proposals for the classification of the acute leukaemias. Br J Haematol 1976; 33: 451-8.

10 Wolk J A, Stuart M J, Davey F R, Nelson D A. Congenital and neonatal leukemia-lymphocytic or myelocytic? Am J Dis Child 1974; 128: 864-6. 
11 Pierce M I. Leukemia in the newborn infant. $J$ Pediatr 1959; 54: 691-706.

12 Rowley J D. Non-random chromosomal abnormalities in haematologic disorders of man. Proc Natl Acad Sci USA 1975; 72: 152-6.

13 First International Workshop on Chromosomes in Leukaemia. Chromosomes in acute non-lymphocytic leukaemia. Br J Haematol 1978; 39: 311-6.
14 Goldman J M. Acute promyelocytic leukaemia. Br Med $J$ 1974; i: 380-2.

Correspondence to Dr M F Whitfield, Department of Paediatrics, Children's Hospital, Western Bank, Sheffield S10 2TH.

Received by 31 July 1979

The following articles will appear in future issues of this journal:

Central nervous system involvement in progressive muscular dystrophy. $M$ Yoshioka, T Okuno, Y Honda, and Y Nakano

Egg and cows' milk allergy in children. $R \boldsymbol{P} K$ Ford and $D$ M Fergusson

Effect of early oral calcium supplementation on serum calcium and immunoreactive calcitonin concentration in preterm infants. L Sann, L David, J A Chayvialle, Y Lasne, and M Bethenod

Respiratory patterns and risk of sudden unexpected death in infancy. $C$ I Franks, $J B G$ Watson, $B$ H Brown, and $E$ F Foster

Effect of treatment of malignant disease on growth in children. $N K$ Griffin and $J$ Wadsworth

Asymptomatic bacteriuria in healthy preterm babies. $M$ Moncrieff, $M$ Bamford, J Benson, and J Bodden 